\title{
Ragam Perspektif Profesi Guru
}

\author{
Misnatun \\ Sekolah Tinggi Ilmu Tarbiyah (STIT) Aqidah Usymuni Terate Sumenep \\ natmurian88@gmail.com
}

\begin{abstract}
The meaning of teachers is related for the life philosophy of a community. Which generally secular western society tends to regard the teacher as an sich companion for students, their interests are not more than just the transfer of knowledge. Even in a more extreme level, religious symbols strictly prohibited into the classrooms. The fact is truly turned to the experience and teachings of Islam. In Islam teachers are not only seen as a 'bank' whose job is only saving and transfer of knowledge, but more that, the teacher is the one who has the moral responsibility, spiritual, and intellectual integrally.
\end{abstract}

\begin{abstract}
Abstrak
Makna guru berhubungan erat dengan falsafah hidup suatu masyarakat. Masyarakat barat yang umumnya sekuler cenderung memandang guru sebagai teman bagi peserta didik, kepentingannya tidak lebih dari sekedar transfer pengetahuan. Bahkan dalam tataran yang lebih ekstrim, simbol-simbol keagamaan dilarang ketat masuk ke dalam ruang-ruang kelas. Kenyataan tersebut sungguh berbalik dengan pengalaman dan ajaran Islam. Dalam Islam guru tidak hanya dipandang sebagai 'bank' pengetahuan yang tugasnya hanya menyimpan dan mentrasfer pengetahuan, tetapi lebih dari itu, guru adalahorang yang memiliki tanggungjawab moral, spiritual, dan intelektual secara integral.
\end{abstract}

\section{A. Guru dalam Tinjauan Filosofis}

Untuk memahami falsafah guru atau pendidik, maka perlu dipahami dahulu hakikat manusia. Pandangan mengenai hakikat manusia secara garis besar dibedakan menjadi dua aliran, yaitu aliran idealisme-spiritualisme dan materialisme. Hakikat manusia menurut pandangan kelompok idealis melihat kemampuan besar dari ide. Hakikat kehidupan manusia ditentukan oleh percaturan antara ide-ide yang saling berlawanan. Dari satu ide atau thesa bertentangan dengan ide yang lain atau anti-thesa dan melahirkan ide pada tingkat yang lebih tinggi atau sintesa yang berakhir pada ide absolut. Manusia paripurna adalah perwujudan dari ide yang absolut itu. ide absolut dapat berupa negara, berupa maha pencipta, dapat pula berupa insan kamil. Akan tetapi, manusia adalah 
makhluk yang serba terbatas yang tidak akan pernah mencapai ide absolut itu. ${ }^{1}$

Sebaliknya paham materialisme melihat manusia tidak lebih dari bagian alam mikro yaitu bagian dari alam materi yang melihat hal yang reslistis yang dapat diraba dan dapat dibentuk dengan kekuatan-kekuatan yang ada di dalam masyarakat. Salah satu kekuatan yang membentuk manusia adalah kekuatankekuatan ekonomi yang tersembunyi di dalam kelas-kelas dalam masyarakat. Oleh sebab itu, tugas pendidikan ialah menyadari akan adanya kepincangankepincangan di dalam masyarakat yang diakibatkan oleh kekuatan-kekuatan tersebut, sehingga dapat merombak kelas-kelas artifisial yang dikonstruksikan oleh kekuatan-kekuatan ekonomi di dalam masyarakat untuk menciptakan masyarakat tanpa kelas. ${ }^{2}$

Dari dua pandangan di atas, dapat diambil beberapa poin sebagai gambaran tentang hakikat manusia. Pertama, manusia adalah satu-satunya makhluk yang dapat mewujudkan kemanusiaannya, karena itu manusia adalah makhluk yang memerlukan pendidikan (animal aducandum). Kedua, manusia adalah animal aducabili, yakni memiliki potensi untuk dididik atau dikembangkan. Sebab manusia tidak lahir dalam keadaan sempurna, tetapi ia lahir dengan serba ketidakberdayaan, sehingga pendidikan mutlak dibutuhkan. Ketiga, manusia adalah makhluk sosial yang memiliki etika. Oleh karenanya dibutuhkan pendidikan untuk mengenalkan nilai-nilai etika yang ada di dalam masyarakat, sehingga ia dapat hidup, beradaptasi, dan melebur dalam budaya yang melingkupinya. ${ }^{3}$

Sebab manusia memiliki potensi untuk dididik dan dikembangkan kemampuannya, maka secara implisit terdapat pengakuan adanya kemampuan manusia untuk menjadi pendidik. Pendidik atau seorang guru merupakan konsekuensi logis dari adanya manusia (baca: anak didik) yang berkebutuhan untuk dididik.Guru adalah profesi paling tua di dunia sebagaimana seorang ibu

\footnotetext{
${ }^{1}$ H. A. R. Tilaar dan Riant Nugroho, Kebijakan Pendidikan, Pengantar Untuk Memahami Kebijakan Pendidikan dan Kebijakan Pendidikan Sebagai Kebijakan Publik, (Yogyakarta: Pustaka Pelajar, Cet ke III, 2012), hlm. 22.

${ }^{2}$ Ibid.

${ }^{3}$ Ibid., hlm. 23-24.
} 
menjadi pendidik bagi anaknya semenjak berada dalam kandungan. Tanpa kehadiran seorang guru yang membimbing dan mengarahkan, seorang anak akan kesulitan dalam menghadapi dan beradaptasi dengan lingkungannya. Jadi, manusia bukan hanya sebagai animal edukandum dan animal educabili, tetapi juga animal edukator. ${ }^{4}$

\section{B. Guru dalam Sejarah Pendidikan Islam}

Cita-cita guru ideal sebenarnya dapat kita lihat pada sosok Nabi Muhammad dalam mendidik umatnya. Keberhasilan Nabi Muhamamad sebagai pendidik didahului dengan bekal kepribadian (personality) yang berkualitas unggul. Dalam sepanjang sejarah, Nabi dicatat sebagai pribadi yang sempurna, berbudi luhur, penuh cinta dan kasih sayang, sabar, sederhana dan gigih dalam mendidik umatnya. Selain kemampuan personality, beliau juga memiliki semangat dan ketajaman dalam membaca, menelaah, dan meneliti berbagai fenomena alam dan sosial.Hal ini menunjukkan, sebagai seorang pendidik, betapa nabi memiliki kepekaan sosial dan semangat keilmuan yang tinggi yang patut diteladani. $^{5}$

Gambaran guru ideal juga dapat ditelusuri dari pendapat-pendapat ulama yang hidup setelah Nabi Muhammad. Pertama menurut Ibn Miskawih, seorang guru menurut Ibn Miskawaih dianggap lebih berperan dalam mendidik kejiwaan muridnya dalam mencapai kejiwaan sejati. Ia membagi jiwa menjadi tiga; quwwatun nathiqah (otak), quwwatun ghadabiyah (hati), dan quwwatun bahamiyah (perut). Menurutnya, seorang guru harus bisa membimbing tiga potensi jiwa ini agar manusia tidak terjatuh pada derajat hewani. Di samping itu, Miskawih mensyaratkan seorang guru, antara lain,bisa dipercaya, pandai, dicintai, sejarah hidupnya tidak tercemar di masyarakat, dan menjadi cermin atau panutan, dan bahkan harus lebih mulia dari orang yang dididiknya. Hal penting yang harus

\footnotetext{
${ }_{5}^{4}$ Ibid., hlm 24.

${ }^{5}$ Muhammad Husain Haekal, Sejarah Hidup Muhammad, penj. Ali Audah, (Jakarta:
} Litera AntarNusa, cet. 38, 2009), hlm. 211-214. 
dimiliki oleh seorang guru dalam kegiatan belajar mengajarnya ialah sikap cinta kasih sayangdan memahami karekteristik serta kecenderungan anak didik. ${ }^{6}$

Kedua, menurut al-Ghazali, menurutnya seorang guru hendaknya memilikikasih sayang kepada murid seperti anaknya sendiri, meneladani rasul, jangan menuntut upah, imbalan, maupun penghargaan, jangan memberi predikat/martabat kepada anak didik sebelum ia pantas dan kompeten untuk menyandangnya, jangan memberi ilmu yang samar sebelum tuntas ilmu yang jelas, mencegah anak didik dari akhlak yang jelek dengan cara sindiran dan tidak tunjuk hidung, tidak menjelek-jelekkan bidang studi lain, menyajikan pelajaran kepada peserta didik sesuai dengan taraf kemampuan mereka, untuk anak didik yang kurang mampu hendaknya memberikan ilmu yang global dan tidak perlu mendetailnya, mengamalkan ilmunya, dan jangan sampai ucapannya bertentangan dengan perbuatannya. ${ }^{7}$

Al-Nahlawipun menganjurkan, hendaknya tingkah laku dan pola pikir guru bersifat rabbani, ikhlas (menegakkan kebenaran dan mencapai ridha allah), sabar dalam mengajarkan berbagai ilmu kepada peserta didik, jujur dalam menyampaikan yang diserukannya, dalam arti menerapkan anjurannya pertama pada dirinya, karena kalau ilmu dan amal sejalan maka perserta didik akan mudah meneladani dalam setiap perkataan dan perbuatannya, membekali diri dengan ilmu dan bersedia mengkaji dan mengembangkannya, mampu menggunakan metode mengajar secara bervariasi, menguasainya dengan baik, mampu menetukan dan memilih metode mengajar sesuai dengan materi pelajaran dan situasi belajar-mengajar, mampu mengelola peserta didik, tegas dalam bertindak, dan meletakkan segala masalah secara proporsional, memperlajari kehidupan psikis peserta didik selaras dengan perkembangannya, tanggap terhadap berbagai kondisi dan perkembangan dunia yang memperngaruhi jiwa, keyakinan, dan pola

\footnotetext{
${ }^{6}$ Syamsul Kurniawan dan Irwan Mahrus, Jejak Pemikiran Tokoh Pendidikan Islam, (Yogyakarta: Arruz Media, 2011), hlm. 66-67.

7 Muhaimin, Paradigma Pendidikan Islam, Upaya Mengektifkan Pendidikan Agama Islam di Sekolah, (Bandung: PT Remaja Rosdakarya, 2002), hlm. 95. Lihat juga di Muhammad Jawwad Ridla, Tiga Aliran Utama Teori Pendidikan Islam (Yogyakarta: PT Tiara Wacana, 2002), hlm. 121.
} 
berpikir peserta didik, memahami problem kehidupan modern, dan bersikap adil antar peserta didik. ${ }^{8}$

Muhammad Athiyah al-Abrasyiberpendapat juga, bahwa seorang guru hendaknya bersikap zuhud dan mengajar hanya karena mencari rida allah, bersih/suci jasmani dan rohani dari dosa, maksiat, penyakit hati, ikhlas dalam bekerja, pekerjaan sesuai dengan ucapan, tidak merasa malu untuk mengatakan 'tidak tahu' jika tidak tahu, merasa butuh menimba ilmu dari peserta didik, pemaaf terhadap peserta didik, mampu menahan diri, menahan amarah, lapang dada, sabar dan tidak mudah marah karena hal sepele, menjaga harga diri dan kehormatan, mencintai peserta didik dan memikirkan mereka seperti anak sendiri, memahami tabiat, minat, kebiasaan, perasaan, dan kemampuan anak didik, menguasai bidang yang diajarkan, dan mendalaminya agar pengajarannya tidak dangkal. $^{9}$

Majid Irsan al-Kailani dalam buku al-Fikr al Tarbawi 'Inda Ibn Taymiyah mengatakan, bahwa seorang guru ideal adalah mereka yang memiliki semangat saling tolong-menolong atas kebajikan dan takwa, menjadi teladan bagi peserta didik dalam kebenaran dan berusaha memlihara akhlak dan nilai-nilai Islam, berusaha menyebarkan ilmunya dan tidak menganggap remeh, dan berusaha mendalami dan mengembangkan ilmu. Sedangkan Brikan Barky al-Qusyairi mensyaratkan agar seorang guru dalam setiap tindakan mengajar harus ditujukan mencari rida Allah, menerapkan ilmunya dalam bentuk perbuatan, amanah dalam mentransformasikan ilmu, menguasai dan mendalami bidang ilmunya, mempunyai kemampuan mengajar, bersikap lemah lembut dan kasih sayang terhadap peserta didik, memahami tabiat, kemampuan dan kesiapan peserta didik. $^{10}$

Begitu pula menurut Ibnu Khaldun, seorang guru haruslah orang yang berpengetahuan luas, terutama tentang peserta didik, dan mempunyai kepribadian yang baik. Pendidik selain sebagai pengajar di dalam kelas, juga harus bisa menjadi suri tauladan bagi peserta didiknya. Menurutnya, keteladanan guru

${ }^{8}$ Ibid., hlm. 96.

${ }^{9}$ Ibid.

${ }^{10}$ Ibid., hlm. 97. 
merupakan keniscayaan dalam pendidikan, sebab para peserta didik menurut Ibnu Khaldun lebih mudah dipengaruhi dengan cara peniruan dan peneladanan serta nilai-nilai luhur yang mereka saksikan dari pada dengan nasehat dan pengajaran atau perintah-perintah. Ibn Khaldun juga menganjurkan agar para guru bersikap dan berperilaku penuh kasih sayang kepada peserta didiknya, mengajar mereka dengan sikap lembut dan saling pengertian, tidak menerapkan perilaku keras dan kasar, sebab sikap demikian dapat membahayakan peserta didik, bahkan dapat merusak mental mereka. ${ }^{11}$

Juga menurut Ibnu Rajab,guru selayaknya mempunyai tanggung jawab yang besar dalam hal pendidikan, pengajaran, dan memberi petunjuk. Para guru lah yang membimbing bagi orang-orang yang bodoh, sesat, dan bagi orang yang terjerumus dalam kesesatan. ${ }^{12}$ Seorang guru harus mempunyai kasih sayang terhadap muridnya dan lemah lembut kepada mereka, menyampaikan ilmu yang dimilikinya terhadap santrinya dan memberi tahu tentang manfaat bagi orang yang menuntut ilmu, sebagaimana Rasulullah mengajarkan kepada para sahabatnya.Di samping memberikan nasehat kepada murid, seorang guru juga memberikan nasehat dan tausiah yang bermanfaat kepada umat dan mengajarkan kepada mereka ilmu yang bermanfaat terhadap kehidupan mereka dan agama mereka. Ibnu Rajab mengatakan sesungguhnya Rasulullah bersabar terhadap menjalankan dakwahnya kepada ummatnya, dan Rasulullah membawa umat dalam kebajikan dan melaksanakan perintah Allah dan berahlak kepada sesama manusia.

Ibnu Sina jugaberpendapat mengenai hal yang sama, menurutnya guru merupakan pendidik yang tugas utamanya adalah mendidik. Maka dari itu, konsep guru yang ditawarkan dalam pemikiran pendidikan Ibnu Sina tentang sosok guru yang baik adalah seorang yang berakal sehat dan cerdas, kuat agamanya, berakhlak mulia, mengetahui cara mendidik akhlak, cakap dalam mendidik anak,

${ }^{11}$ Syamsul kurniawan, Jejak Pemikiran...., hlm. 108. Lebih jelas silahkan rujuk di Ibn Khaldun, Muqaddimah, (Jakarta: Pustaka Firdaus, cet-10, 2011), penj:Ahmadie Thoha, hlm. 534538 .

${ }^{12}$ Hasan Ibn Ali Ibn Hasan Al-Hijaj, al-Fikru Tarbawi 'Inda Ibnu Rajab al-Hanbali (Jidah: Andalus al-Hodro', 1996 M/ 1417 H), hlm. 284. 
berpenampilan tenang, sabar, berwibawa, berkepribadian yang tangguh, berwawasan yang luas dan tidak statis, manis tutur katanya, dan berhati suci. ${ }^{13}$

Selain itu, Ibnu Sina juga menganjurkan, seorang guru atau pendidik hendaklah orang yang mengetahui dan mengenal betul karakteristik atau kecendrungan anak yang bersangkutan, disamping itu dilihat juga tingkat kecerdasannya. Ini dilakukan, agar bakat dan cita-cita yang mejadi dambaan anakanak sesuai dengan kemampuan yang dimilikinya. ${ }^{14}$ Jika anak suka mempelajari suatu ilmu secara intlektual dan ilmiah, tunjukkan dan arahkan pada hal tersebut, dan berilah kesempatan untuk mempelajari sesuatu ilmu yang dinginkan. Jika ia senang dengan hal-hal yang bersifat praktis, berilah ia motivasi untuk mencapai hal yang diinginkannya.

Konsep guru yang sudah dikemukakan oleh Ibnu Sina diatas sudah sangat jelas, bahwa seorang guru yang melakukan tugas mendidik harus memiliki sifatsifat yang sudah disebutkan diatas. Memang seorang guru itu haruslah yang berakal sehat, bijaksana dalam bertindak, menyelesaikan tugasnya dengan cara yang baik, cermat dalam berpikir, berpendapat sesuai dengan nilai-nilai yang baik dan mengetahui terhadap karakteristik anak. dan seorang tidak boleh berperilaku kasar dan emosional, karena hal itu tidak baik dan akan berpengaruh terhadap kepribadian anak didik.

Disamping itu, seorang guru sudah seharusnya menjadi suri tauladan atau panutan yang baik bagi peserta didiknya, karena biasanya seorang siswa atau murid-murid itu selalu melihat terhadap tingkah laku gurunya. Kalau seorang guru tidak memberikan contoh yang baik, maka murid tersebut sulit rasanya untuk berbuat baik juga. Itulah sebabnya, guru itu harus seorang yang dapat dijadikan panutan yang mendalam agamanya dan berakhlak mulia. Dalam hal ini, Ibnu Qoyyim menyebut pendidik dengan sebutan alim rabbani. Jadi menurut Ibnu Qayyim, seorang alim tidak akan disifati dengan rabbani, kecuali benar-benar mengamalkan dan mengajarkan ilmunya.

Dari beberapa pendapat tokoh Islam yang disebutkan di atas, ada satu yang

\footnotetext{
${ }^{13}$ Syamsul Kurniawan, Jejak Tokoh.... hlm. 85.

14 Muhammad' Athiyah Al-Abrasyi, Beberapa Pemikiran Pendidikan Islam, Terj,
} Syamsuddin Asyrofi (Yogyakarta: Titian Ilahi Pres, 1996), hlm. 100-101 
harus digarisbawahi. Guru dalam pendidikan Islam dipandang sebagai organ sentral dalam pendidikan yang berfungsi sebagai pembimbing moral, spiritual, dan intelektual. Dalam setiap generasi, di dunia Islam, khususnya dalam bidang pendidikan tidak pernah memisahkan spiritualitas dan moralitas dari pendidikan. Intelektualitas, moralitas, dan spiritualitas merupakan satu kesatuan yang dikonsep secara seimbang dalam pendidikan Islam. Jadi sebagai implikasinya, guru bukan hanya sebagai pengirim/pemindah ilmu pengetahuan (transferer of knowledge) kepada anak didik, melainkan juga sebagai pembimbing moral dan spiritual. Oleh karenya, kompetensi sebagaimana guru dibicarakan oleh tokohtokoh Islam, tidak hanya meliputi kompetensi pedagogis dan profesional saja, melainkan juga kompetensi kepribadian (personality) yang sangat ditekankan dalam pendidikan Islam.

Kompetensi pedagogik merupakan kemampuan mengelola pembelajaran. Dalam hal ini tokoh Islam seperti Miskawih, Ibn Khaldun, Ibn Sina, dan lainnya, mengatakan bahwa sebelum memulai mendidik dan melakukan praktik pengajarannya, seorang pendidik seharusnya memahami karakter, latar belakang, kemampuan, kecenderungan, bakat dan minat anak didik. Sehingga dalam memberikan pemahaman dan pengajaran dapat disesuaikan dengan kondisi anak didik. Sedangkan kompetensi profesional ialah kemampuan yang meliputi penguasaan materi, keluasan wawasan, penguasaan metode pembelajaran, dan secara konsisten mengembangkan kemampuan dan keilmuan adalah ciri-ciri guru yang profesional menurut tokoh Islam.

Selain kompetensi pedagogis dan profesional, kompetensi kepribadian (personality) merupakan kompetensi yang paling mendapat banyak perhatian di kalangan tokoh Islam. Karena pada dasarnya, pendidikan Islam adalah pembinaan moral atau akhlak anak didik menuju manusia yang sempurna, sebagaimana hal ini mencontoh misi kenabian Nabi Muhammad.Dalam pemikiran Islam, seorang pendidik digambarkan sebagai orang yang mampu menjadi panutan dan teladan bagi anak didik dan masyarakat, menjaga perbuatannya, jangan sampai yang diperbuat melenceng dari yang dikatakannya kepada anak didik, mengamalkan 
ilmunya, kuat agamanya, berpenampilan tenang dan sederhana, ikhlas, penuh kasih sayang, perhatian, dan berbuat adil antar anak didik. Tanpa memiliki kompetensi yang terakhir ini, betapapun seseorang memiliki ilmu yang banyak dan wawasan yang luas, dalam konsep pendidikan Islam tidak diterima atau diakui sebagai seorang guru/pendidik.

\section{Guru dalam Perspektif Barat; Sebuah Perbandingan}

Secara periodik teori pendidikan Barat dibagi menjadi tiga aliran, yakni aliran tradisional, modern, dan kontemporer. Teoripendidikan dalam aliran-aliran ini direkonstruksi dari pemikiran filsafat yang berkembang di Barat, khususnya di Eropa. Tiga aliran tersebut masih dipecah menjadi lebih banyak lagi aliran dan teori pendidikan yang memiliki pandangan yang bersinggungan satu sama lain. Teori pendidikan tradisional terdiri dari aliran idealisme, realisme, dan neosklastik. Sedangkan teori modern meliputi eksistensialisme dan pragmatisme. Dan teori kontemporer terdiri dari progresifisme, humanisme, parenialisme, esensialisme, rekonstruksionisme, dan behaviorisme.

Aliran filsafat tradisional, yakni pada aliran idealisme, guru ditempatkan pada posisi krusial, guru dipandang sebagai diri yang lebih dekat dengan Yang Absolut daripada murid. Sebab guru dianggap sebagai orang yang memiliki pengetahuan lebih tentang realitas, sehingga mampu bertindak sebagai perantara antara diri mikrokosmis anak didik dan Diri Absolut makrokosmis. Ia adalah panutan bagi anak didik untuk diikuti, baik dalam kehidupan intelektual maupun sosial.

Berbeda dengan pandangan realisme, oleh aliran ini, guru dipandang sebagai pengamat yang lebih kompleks yang mengetahui tentang hukum-hukum kosmos. Karena itu, peran guru adalah memberi informasi (transfer pengetahuan) yang akurat menyangkut realitas dengan cara yang paling efisien dan cepat. Pengajaran hanya berfungsi sebagai demonstrasi regularitas dan hukum-hukum alam. Oleh karenya, bias-bias dan kepribadian guru dalam pandangan realisme ini 
sebisa mungkin harus dihilangkan, termasuk juga bias agama. ${ }^{15}$

Dalam filsafat tradisional, juga ada filsafat neoskolastik yang memandang guru sebagai seorang yang berdisiplin mental dengan kemampuan mengembangkan rasio, ingatan, dan daya kemauan pada diri anak didiknya. Sedikit berbeda dengan neoskolatik gerejawi yang melihat peran guru sebagai peran seorang pemimpin spiritual dan juga seorang berdisiplin mental. Ia adalah orang yang mengarahkan anak didik tidak hanya melalui ranah rasio, melainkan juga melalui ranah keimanan. ${ }^{16}$ Aliran filsafat neoskolastik ini nampaknya ingin menjembatani perbedaan antara aliran idealisme dan realisme, meskipun ia lebih condong pada aliran idealisme.

Menurut Knight, meskipun memiliki perbedaan-perbedaan, dalam filsafat tradisional ini juga memiliki persamaan, yakni sama-sama memandang guru sebagai sosok otoritatif yang mengetahui apa yang perlu dipelajari murid, masingmasing menyusun kurikulum atas dasar materi yang menitikberatkan pada muatan intelektual, dan masing-masing melihat pendidikan dan sekolah dalam corak konservatif karena fungsi keduanya adalah untuk mentransfer warisan masa lampau ke generasi sekarang. ${ }^{17}$

Aliran tradisional segera disusul oleh aliran modern, yakni aliran pragmatisme dan eksistensialisme. Dalam aliran pragmatisme guru dilihat sebagai pendamping subjek didik dalam pengalaman pendidikan, karena seluruh aktivitas kelas setiap harinya menghadapi dunia yang berubah. Namun, guru adalah pendamping yang lebih berpengalaman dan karenanya dipandang sebagai pemandu atau pengarah. Ia adalah orang yang menasihati dan memandu aktivitasaktivitas subjek didik yang muncul di luar apa yang dibutuhkan subjek didik, namun ia tidak mendasarkan aktivitas-aktivitas kelas pada apa yang merasa dibutuhkan oleh guru, melainkan berdasarkan kebutuhan anak didik. ${ }^{18}$ Hampir sama dengan aliran eksistensialisme, dalam aliran ini guru dipandang sebagai

${ }^{15}$ George R. Knight, Filsafat Pendidikan, penj. Mahmud Arif, (Yogyakarta: Gama Media, 2007), hlm. 87-88.

${ }^{16}$ Ibid., hlm. 101.

${ }^{17}$ Ibid., hlm. 103.

${ }^{18}$ Ibid., hlm. 120. 
fasilitator. Namun dalam peran ini, guru masih mau menghargai aspek-aspek emosional dan irasional individu-individu dan mau berupaya serius mengarahkan subjek didik ke pemahamannya yang lebih baik tentang diri sendiri. ${ }^{19}$

Lebih aktual lagi kita lihat teori pendidikan pada aliran filsafat kontemporer. Dalam aliran progresivisme, peran guru sebagai penasihat, pembimbing, dan pemandu daripada sebagai rujukan otoriter (tak bisa dibantah) dan pengarah ruang kelas. Peran guru dapat dilihat sebagai peran pembantu subjek didik yang belajar secara mandiri, sehingga ia akan menjadi sosok orang dewasa yang mandiri dalam lingkungan yang berubah. Guru tidak bisa menjadi rujukan otoriter, sebab realitas selalu berubah, dan tidak seorang pun yang mengetahui realitas masa depan. Guru hanya sebagai pembantu dan penasehat ketika anak didik menemui kebuntuan dalam belajar. ${ }^{20}$

Demikian juga dalam aliran humanisme, guru dipandang sebagai partner, teman belajar yang senantiasa membantu mencapai keinginan-keinginan anak didik. Guru tidak bisa memaksakan kehendaknya, tetapi justru harus menerima perbedaan dan pertentangan dari anak didik. ${ }^{21}$ Hal ini ditentang oleh aliran parenialisme, menurut aliran ini, meskipun realitas empirik selalu berubah-ubah, tetapi ada nilai abadi dalam kehidupan manusia yang tetap ada sepanjang waktu. Oleh karenanya, dalam pandangan ini, guru tidak hanya sebagai pembantu anak didik, melainkan sebagai pembimbing yang mengantarkan dan mengenalkan anak didik pada kebenaran dan kebijaksanaan masa lampau yang tetap relevan sampai saat ini.

Selain ditentang oleh esensialisme, progresivisme juga ditentang oleh kalangan esensialis. Menurut mereka guru bukanlah orang yang mengikuti keinginan murid, tetapi sebaliknya, guru adalah orang yang mengetahui apa yang dibutuhkan oleh peserta didik, sehingga guru berada pada posisi lokus otoritas ruang kelas. Disamping itu, guru sebagai wakil dari komunitas orang dewasa yang menuntut rasa hormat dari anak didik. Jika kepadanya tidak diberikan penghormatan, maka guru berhak untuk menata tatanan kedisiplinan yang akan

\footnotetext{
${ }^{19}$ Ibid., hlm. 137.

${ }^{20}$ Ibid., hlm. 151-152.

${ }^{21}$ Ibid., hlm. 162.
} 
membawa pada suasana belajar yang kondusif dan tertib. ${ }^{22}$ Jadi dalam aliran ini masih memperhatikan otoritas guru dan nilai-nilai etis hubungan antara orang dewasa (guru) dengan anak didik. Begitu pun dengan aliran rekonstruksionisme yang mempercayakan guru sebagai instrumen utama perubahan sosial. ${ }^{23}$

Nilai-nilai etis atau moralitas kembali diangkat oleh kalangan behavioristik. Menurut mereka, pendidikan adalah sebuah proses rekayasa tingkah laku. Oleh karenya tugas guru adalah mengarahkan anak didik untuk bertingkah laku seperti yang diidealkan. Lingkungan sekolah direkayasa sedemikian rupa menjadi lingkungan yang kondusif untuk membentuk pribadi anak didik yang baik. Pembiasaan oleh guru yang ditularkan kepada anak didik adalah upaya penting untuk menciptakan kondisi belajar yang kondusif dan efektif. ${ }^{24}$

Di samping teori-teori kontemporer yang telah disebut di atas, ada teori kritis yang dimotori oleh Frankfurt, Antonio Gramsci, dan Paulo Freire. Dalam aliran ini, guru tidak cukup memiliki kemampuan pedagogis dan profesional, tetapi juga harus memiliki basis politis yang diintegrasikan ke dalam pengajarannya. Guru lebih dipandang sebagai transformator yang meletakkan muatan politis dalam semua aktivitas pendidikan dan pengajaran. Pilihan pengetahuan yang diajarkan, model relasi yang dibangun, semuanya harus bersifat politis. Anak didik tidak diarahkan untuk mendapat pekerjaan semata, seperti pragmatisme, tetapi lebih diarahkan agar mampu menjadi warga negara yang kritis, aktif, dan bertanggungjawab. ${ }^{25}$

Pandangan-pandangan di atas menunjukkan, bahwa guru dalam perspektif Barat lebih dilihat sebagai pembimbing intelektual semata, bahkan sebagai pembantu yang tidak dibolehkan mencampuri keinginan anak didik. Dimensi moralitas dan spiritualitas dalam pendidikan Barat kurang mendapatkan ruang dalam proses pendidikan. Bahkan dalam pandangan realisme guru dianjurkan untuk membuang bias-bias pribadi dan agama sejauh mungkin, karena pendidikan

\footnotetext{
${ }^{22}$ Ibid., hlm. 181.

${ }^{23}$ Ibid., hlm. 187

${ }^{24}$ Ibid., hlm. 198-199.

${ }^{25}$ M. Agus Nuryatno, Mazhab Pendidikan Kritis, Menyingkap Relasi Pengetahuan Politis dan Kekuasaan, (Yogyakarta: Resist Book, 2008), hlm. 86-87.
} 
hanya dipandang untuk mentransfer hukum-hukum alam dan menjelaskan realitas empirik semata. Dalam hal ini, aliran yang masih dapat dikecualikan dari sekularisme ini adalah pandangan idealisme dan neoskolastik yang masih mempercayai hal yang bersifat metafisik, yang oleh idealisme disebut Realitas Absolut.

Behavioristik juga salah satu di antara pandangan filsafat Barat yang menaru perhatian terhadap moralitas atau nilai-nilai etis sebagai salah satu cara manusia agar kehidupannya lebih beradab. Sehingga sekolah dan elemen di dalamnya direkayasa sedemikian rupa untuk membentuk pribadi yang ideal menurut mereka. Namun moralitas dalam behavioristik tidak berangkat dari seruan agama, tetapi moralitas yang dilandaskan pada norma sosial yang berlaku di sana. Berbeda dalam pendidikan Islam yang menjadikan agama sebagai standar dalam segala sendi kehidupan masyarakat muslim.

Moralitas, intelektualitas, dan spiritualitas dalam pendidikan Islam seperti bangunan segitiga yang sisi-sisinya tidak dapat dipisahkan, semua sisi saling menyangga dan mengokohkan satu sama lain.Oleh karenanya, dalam pendidikan Islam tidak pernah terjadi sekularisasi yang memisahkan agama dan moralitas dari proses pendidikan. Inilah secara garis besar yang membedakan konsep pendidikan Islam dengan konsep pendidikan di Barat. Begitu pun dengan peran guru, di Barat guru hanya mendapat tuntutan kompetensi pedagogis dan profesional, akan tetapi dalam Islam, tanggungjawab guru lebih kompleks lagi, selain tanggungjawab terhadap kompetensi pedagogik dan profesionalisme, guru juga dituntut menjadi pribadi ideal yang diinginkan oleh agama dan masyarakat.

\section{Konsep Normatif Guru di Indonesia}

Dalam UU RI No. 14 tahun 2005 pasal 1 ayat (1) disebutkan, bahwa guru adalah pendidik profesional dengan tugas utama mendidik, mengajar, membimbing, mengarahkan, melatih, menilai, dan mengevaluasi peserta didik pada pendidikan anak usia dini jalur pendidikan formal, pendidikan dasar, dan 
pendidikan menengah, sedangkan untuk pendidikan tinggi disebut dosen. Selanjutnya pada ayat (4) dijelaskan, bahwa yang dimaksud profesional adalah pekerjaan atau kegiatan yang dilakukan oleh seseorang dan menjadi sumber penghasilan kehidupan yang memerlukan keahlian, kemahiran, atau kecakapan yang memenuhi standar mutu atau norma tertentu serta memerlukan pendidikan profesi.

Adapun prinsip profesionalitas dijelaskan pada pasal 7 yang meliputi; (1) memiliki bakat, minat, panggilan jiwa, dan idealisme; (2) memiliki komitmen untuk meningkatkan mutu pendidikan, keimanan, ketakwaan, dan akhlak mulia; (3) memiliki kualifikasi akademik dan latar belakang pendidikan sesuai dengan bidang tugas; (4) memiliki kompetensi yang diperlukan sesuai dengan bidang tugas; (5) memiliki tanggungjawab atas pelaksanaan tugas keprofesionalan; (6) memperoleh penghasilan yang ditentukan sesuai dengan prestasi kerja; (7) memiliki kesempatan untuk mengembangkan keprofesionalan secara berkelanjutan dengan belajar sepanjang hayat; (8) memiliki jaminan perlindungan hukum dalam melaksanakan tugas keprofesionalan, dan; (9) memiliki organisasi profesi yang mempunyai kewenangan profesi yang mempunyai kewenangan mengatur hal-hal yang berkaitan dengan tugas keprofesionalan guru.

Kualifikasi akademik yang disebut pada poin kedua adalah kualifikasi yang harus diperoleh melalui pendidikan tinggi program sarjana (S1) atau program diploma empat (D IV). Sedangkan kompetensi guru yang disebut dalam poin tiga adalah kompetensi yang meliputi kompetensi pedagogik, kompetensi kepribadian, kompetensi sosial, dan kompetensi profesional yang diperoleh melalui pendidikan profesi. ${ }^{26}$

Di samping standar profesionalisme yang dikonsep oleh pemerintah, guru profesional dalam pendidikan modern juga dituntut memiliki kompetensikompetensi yang meliputi; (1) mengenal peserta didik secara mendalam; (2) menguasai bidang studi; (3) menyelenggarakan pembelajaran yang mendidik; (4) meningkatkan profesionalitas secara berkelanjutan; dan (5) meningkatkan

${ }^{26}$ Republik Indonesia, Undang-Undang Guru dan Dosen (UU RI No. 14 Th. 2005), (Jakarta: Sinar Grafika, cet. II, 2009), hlm. 8-9. 
profesionalitas pelaksanaan tugas sebagai pendidik (kepribadian, pembelajaran, dan komunikasi). ${ }^{27}$

Lebih kompleks lagi guru profesional dikonsep oleh Mulyasa. Menurutnya, guru seabgai pendidik profesional diidealkan mampu menjadi agen pembelajaran yang edukatif, yaitu dapat menjadi fasilitator, motivator, pemacu, perekayasa, dan inspirator pembelajaran. ${ }^{28}$ Sebagai fasilitator pembelajaran, berarti pendidik; (1) membantu memudahkan dan membantu peserta didik dalam belajar; (2) tidak berperan sebagai satu-satunya sumber belajar, melainkan berperan sebagai salah satu sumber belajar; (3) berupaya memberdayakan sumber daya peserta didik sehingga mereka dapat berkembang optimal.

Sebagai motivator pembelajaran, berarti pendidik, (1)mendorong dan menggerakkan peserta didik agar mereka semakin giat dalam belajar; (2) memiliki kemampuan membangkitkan semangat dan kesadaran diri peserta didik sehingga mereka terbiasa belajar; (3) dapat menggunakan prinsip-prinsip "ing ngarso sung tulodo, ing madyo mangun karso, dan tut wuri handayani”.

Sebagai pemacu pembelajaran, guru (1) dituntut memiliki kemampuan mengoptimalkan berbagai kemampuan belajar peserta didik untuk selalu dalam kondisi prima dan semakin giat belajar; (2) dituntut selalu berada di sekitar peserta didik dan memahami berbagai kelebihan dan kelemahan peserta didiknya; (3) mengetahui kapan peserta didik harus belajar dan kapan peserta didik harus beristirahat.

Sebagai perekayasa pembelajaran, guru atau dosen dituntut (1) mampu merancang, mengembangkan, melaksanakan, mengevaluasi, dan menyempurnakan kegiatan pembelajaran sesuai kebutuhan peserta didik dan masyarakat; (2) tidak memandang kegiatan pembelajaran sebagai kegiatan rutinitas, tetapi dipandang sebagai kegiatan yang dinamis dan inovatif yang perlu dikembangkan dan dimutakhirkan secara terus menerus sesuai kebutuhan anak didik dan tuntutan zaman.

\footnotetext{
${ }^{27}$ Agus, Mazhab...., hlm. 84.

${ }^{28}$ E. Mulyasa, Standar Kompetensi dan Sertifikasi Guru, (Bandung: Rosdakarya, 2007),
} hlm. 53-74. 
Sebagai inspirator pembelajaran guru (1) dituntut memiliki peranan sebagai pemberi inspirasi pembelajaran kepada peserta didik; (2) wajib mengemukakan berbagai gagasan, kegiatan, dan tugas-tugas pembelajaran yang dapat menyebabkan peserta didik belajar; (3) wajib memprakarsai kegiatan belajar peserta didik; (4) mengetahui ke mana dan kegiatan-kegiatan belajar apa saja yang akan dilakukan peserta didik.

Di samping sebagai agen pembelajaran yang edukatif, dalam konteks pendidikan modern guru juga diidealkan memiliki empat kompetensi, yaitu kompetensi pedagogis, kepribadian, profesional, dan sosial. kompetensi pedagogik merupakan kemampuan mengelola pembelajaran yang meliputi pemahaman terhadap peserta didik, perancangan dan pelaksanaan pembelajaran dan pengembangan peserta didik untuk mengaktualisasikan berbagai potensi yang dimiliki.

Kompetensi kepribadian ditunjukkan dengan ciri-ciri kepribadian yang mantap, berakhlak mulia, arif, berwibawa, serta menjadi teladan bagi peserta didik. Kompetensi profesional adalah kemampuan untuk menguasai materi pembelajaran secara luas dan mendalam yang memungkinkan untuk membimbing peserta didik memenuhi standar kompetensi lulusan yang ditetapkan. Sedangkan kompetensi sosial merupakan kemampuan untuk berkomunikasi dan berinteraksi secara efektif dan efisien dengan peserta didik, sesama pendidik, tenaga kependidikan, orang tua/wali, dan warga masyarakat sekitar. ${ }^{29}$

Untuk lebih memperjelas terminologi profesional, Mukhtar Lutfi menetapkan delapan kriteria yang harus dipenuhi oleh seseorang agar pekerjaannya disebut sebagai profesi. ${ }^{30}$ Apabila ditarik ke dalam pendidikan, dalam hal ini adalah profesi guru, maka akan menghasilkan kriteria sebagai berikut, (1) mendidik dan mengajar adalah pekerjaan yang menjadi panggilan hidup yang dilakukan sepenuhnya yang berlangsung dalam waktu yang lama, bahkan seumur hidup; (2) mendidik dan mengajar adalah pekerjaan yang dilakukan atas dasar pengetahuan dan kecakapan/keahlian yang khusus dipelajari;

\footnotetext{
${ }^{29} \mathrm{Ibid}$.

${ }^{30}$ Syarifuddin Nurdin dan Basyiruddin Usman, Guru Profesional dan Implementasi
} Kurikulum, (Jakarta: Ciputat Pers, 2002), hlm. 16-17. 
(3) praktik mendidik dan mengajar dilakukan menurut teori, prinsip, prosedur, dan aggapan dasar yang sudah baku secara umum (universal), sehingga dapat dijadikan pegangan atau pedoman dalam pemberian pelayanan terhadap mereka yang membutuhkan; (4) mendidik dan mengajar dimaknai sebagai pengabdian pada masyarakat, bukan untuk mencari keuntungan materi/finansial bagi diri sendiri; (5) mendidik dan mengajar adalah pekerjaan yang mengandung unsurunsur kecakapan diagnostik dan kompetensi aplikatif terhadap orang atau lembaga yang dilayani; (6) mendidik dan mengajar dilakukan secara otonom atas dasar prinsip-prinsip atau norma-norma yang ketetapannya hanya dapat diuji atau dinilai oleh rekan-rekannya seprofesi; (7) memiliki kode etik yaitu norma-norma tertentu sebagai pegangan atau pedoman yang diakui serta dihargai oleh masyarakat; dan (8) mendidik dan mengajar dilakukan untuk melayani mereka yang membutuhkan pelayanan (klien) yang pasti dan jelas subyeknya.

Profesionalitas yang dikonsep oleh Lutfi di atas sedikit berbeda dengan Rochman Natawidjaja. Menurut Natawidjaja, dalam pekerjaan profesi terdapat sistem imbalan terhadap jasa layanannya yang adil dan baku, sedangkan menurut Lutfi sebagaimana ditulis dalam poin ke empat, pekerjaan profesi adalah pekerjaan yang ditujukan untuk mengabdi pada masyarakat, bukan untuk mencari keuntungan finansial. Penulis memahami, Lutfi tidak sedang melarang guru untuk menerima imbalan, tetapi dianggap keliru apabila seorang guru melandaskan pekerjaannya pada pemberian imbalan. Sebaliknya, menurut Natawidjaja, untuk diakui sebagai pekerjaan profesi, berarti harus ada sistem imbalan yang jelas dan baku terhadap jasa layanan guru. Usulan Natwidjaja ini nampaknya mendapat respon dari pemerintah yang menetapkan gaji atau honor kepada guru sesuai dengan standar dan ketentuan sebagaimana diatur dalam pasal 14-19 dalam UU Guru dan Dosen No. 14 Tahun 2005.

Mengenai kode etik guru sebagaimana disebut oleh Lutfi dan Natawidjaja penulis tidak menemukan perincian yang detail seperti yang dikonsep oleh tokohtokoh Islam terdahulu, hanya saja disebutkan minimalnya, yakni (1) berkompeten dalam mengajarkan bidang studinya; (2) profesional dalam melaksanakan tugas guru; (3) terampil dan benar dalam melaksanakan kinerja guru. Kode etik ini 
menurut Dearden, sebagaimana dikutip oleh Djohar, pada dasarnya adalah untuk mengendalikan kinerja guru. Oleh karena itu, guru juga membawa amanat profesi yang dapat diukur dan dikontrol perilaku penyimpangannya dari profesi guru. ${ }^{31}$

\section{E. Analisis dan Komparasi; Guru dalam Perspektif Tokoh Islam Klasik dan Perspektif Modern di Indonesia}

Secara konseptual, guru dalam perspektif modern, sebagaimana termuat dalam UU Guru dan Dosen, serta konsep yang ditulis oleh Mulyasa dan lainnya, telah memuat konsep-konsep pendidikan dalam sejarah Islam. Konsep-konsep tersebut adalah sebagai berikut:

1. Guru dipandang sebagai pembimbing intelektual dan moral anak didik. Oleh sebab itu, selain dituntut memiliki kompetensi profesional, guru juga berarti harus mampu menjadi figur teladan bagi anak didik (kompetensi personal).

2. Dalam melaksanakan proses pendidikan dan pengajaran, guru harus mampu memahami kondisi anak didik yang meliputi, latar belakang, kemampuan, karakter, bakat, dan minat, sehingga dalam proses membimbing guru dapat menyesuaikannya dengan kemampuan dan kecenderungan anak didik. Dalam hal ini, guru dituntut memiliki kompetensi pedagogik dan sosial, agar proses pengajaran dan pendidikan lebih kondusif dan tepat sasaran.

Namun demikian, ada perbedaan atau pergeseran dari konsep guru yang dalam sejarah Islam dengan konsep modern saat ini, khususnya di Indonesia. Guru dalam sejarah Islam didefinisikan sebagai orang yang memiliki pengetahuan, khususnya pengetahuan agama, serta mampu mengajarkannya. Di samping itu, pendidikan Islam dalam sejarah yang berlangsung sejak 13 abad yang lalu, lebih menekankan pendidikan moral dan akidah (spiritual). Oleh karenanya, kompetensi untuk menjadi guru tidak cukup memiliki ilmu saja, akan tetapi, ilmu yang dimiliki sudah terintegrasi dalam diri seorang guru. Dalam artian, seorang guru adalah figur sentral yang perilaku, tindakan, dan sikapnya menjadi panutan anak didik dan masyarakat.

31 Djohar, Guru, Pendidikan dan Pembinaannya (Penerapan dalam Pendidikan dan UU Guru), (Yogyakarta: Grafika Indah, 2006), hlm. 40. 
Guru dalam konsep modern telah mengalami formalisasi hampir dalam segala aspeknya. Kualifikasi guru bukan lagi sekedar memiliki keluasan ilmu dan kedalaman spiritual seperti ditekankan dalam sejarah Islam, melainkan orang yang menempuh pendidikan formal sesuai dengan jenjang yang ditentukan. Sedikitnya mereka telah memiliki ijazah formal Diploma IV atau Strata 1 pada bidang studi yang diampunya. Di samping itu, pengakuan ijazah guru oleh pemerintah harus dikeluarkan oleh Perguruan Tinggi yang telah terakreditasi secara formal, di luar itu, maka gelar guru tidak akan diakui oleh pemerintah.

Demikian juga pergeseran profil guru agama, Steenbrink dari hasil penelitiannya mengatakan, bahwa guru agama saat ini tidak lagi memprioritaskan kiai yang disamping memiliki pemahaman ilmu agama yang mendalam juga sebagai orang yang taat beragama, akan tetapi diprioritaskan orang yang memiliki gelar Drs. atau telah menempuh jenjang pendidikan S1. ${ }^{32}$ Lebih aktual lagi, guru saat ini diwajibkan untuk memiliki sertifikasi sebagai pengakuan formal sebagai guru yang profesional dan berkompeten dalam mendidik siswa.

Sebagai konsekuensi dari formalisasi di atas, guru saat ini tidak lagi dipandang sebagai seseorang yang karismatik dan wara'. Kepercayaan dan pandangan masyarakat kepada guru saat ini sama dengan pandangannya kepada orang yang memiliki profesi di luar guru, seperti dokter, pegawai kantoran, bahkan cenderung disamakan dengan pekerja rendahan lainnya. Hal ini disebabkan oleh fenomena yang seringkali terjadi di lingkungan pendidikan sendiri, seorang guru melakukan praktik komersialisasi di sekolah, guru memacari muridnya, kepala sekolah mencabuli anak didik, dan masih banyak lagi kejadian memalukan yang diperbuat oleh guru di sekolah.

Di samping profil guru yang disebutkan di atas, perubahan lain terjadi pada sistem upah atau gaji. Jika dulu ulama-ulama masih mempertentangkan boleh tidaknya menerima atau meminta upah dari anak didik, sekarang upah guru telah terkonsep dan terukur sedemikian rupa sesuai dengan pangkat formalnya. Bahkan dengan pengangkatan Pegawai Negeri Sipil (PNS) dan adanya program

${ }^{32}$ Karel A. Steenbrink, Pesantren Madrasah Sekolah, Pendidikan Islam dalam Kurun Modern, Jakarta: LP3ES, cet. II, 1994. 
sertifikasi, kesejahteraan guru telah mengalami peningkatan. Namun peningkatan gaji ini mendapat kritik yang cukup keras dari para pengamat pendidikan seperti Darmaningtyas yang mengatakan "mubazir memberikan gaji tinggi kepada guru". ${ }^{33}$ Hal ini disebabkan oleh fenomena peningkatan gaji yang tidak dibarengi dengan peningkatan kualitas diri seorang guru. Bermacam dana tunjangan yang diberikan oleh pemerintah dihabiskan untuk membeli sesuatu di luar kebutuhan pendidikan.Sehingga maklum, apabila kualitas guru yang masih sangat rendah menuai kritikan dari banyak kalangan.

\section{DAFTAR PUSTAKA}

Al-Abrasyi, Muhammad' Athiyah. 1996. Beberapa Pemikiran Pendidikan Islam, Terj, Syamsuddin Asyrofi. Yogyakarta: Titian Ilahi Pres.

Ali, Hasan Ibn, dan Ibn Hasan Al-Hijaj. 1996. Al-Fikru Tarbawi 'Inda Ibnu Rajab al-Hanbali. Jidah: Andalus al-Hodro.

Darmaningtyas, 2007. Pendidikan Rusak-Rusakan. Yogyakarta: LkiS

Djohar. 2006. Guru, Pendidikan dan Pembinaannya (Penerapan dalam Pendidikan dan UU Guru). Yogyakarta: Grafika Indah.

Haekal, Muhammad Husain. 2009. Sejarah Hidup Muhammad, penj. Ali Audah. Jakarta: Litera AntarNusa.

Khaldun, Ibn. 2011. Muqaddimah. penj:Ahmadie Thoha. Jakarta: Pustaka Firdaus

Knight, George R. 2007. Filsafat Pendidikan, penj. Mahmud Arif. Yogyakarta: Gama Media.

Kurniawan, Syamsul, dan Irwan Mahrus. 2011. Jejak Pemikiran Tokoh Pendidikan Islam. Yogyakarta: Arruz Media.

Muhaimin. 2002. Paradigma Pendidikan Islam, Upaya Mengektifkan Pendidikan Agama Islam di Sekolah. Bandung: PT Remaja Rosdakarya.

Mulyasa, E. 2007. Standar Kompetensi dan Sertifikasi Guru. Bandung: Rosdakarya.

Nurdin, Syarifuddin dan Basyiruddin Usman. 2002. Guru Profesional dan Implementasi Kurikulum. Jakarta: Ciputat Pers.

Nuryatno, M. Agus. 2008. Mazhab Pendidikan Kritis, Menyingkap Relasi Pengetahuan Politis dan Kekuasaan. Yogyakarta: Resist Book.

${ }^{33}$ Selengkapnya baca Darmaningtyas, Pendidikan Rusak-Rusakan, (Yogyakarta: LkiS, cet. II, 2007), hlm. 131-140. 
Republik Indonesia. 2009. Undang-Undang Guru dan Dosen (UU RI No. 14 Th. 2005). Jakarta: Sinar Grafika.

Ridla, Muhammad Jawwad. 2002. Tiga Aliran Utama Teori Pendidikan Islam Yogyakarta: PT Tiara Wacana.

Steenbrink, Karel A. 1994. Pesantren Madrasah Sekolah, Pendidikan Islam dalam Kurun Modern. Jakarta: LP3ES.

Tilaar, H. A. R. dan Riant Nugroho. 2012. Kebijakan Pendidikan, Pengantar Untuk Memahami Kebijakan Pendidikan dan Kebijakan Pendidikan Sebagai Kebijakan Publik. Yogyakarta: Pustaka Pelajar. 